committee, of which Mr. A. L. F. Norrington, President of Trinity College, was chairman, on matters arising out of the earlier Harrison Report on this subjoct, summarizes the views of the Colloges and concludes that the root of the matter is status, and this only fellowship can provide (Pp. 13. Supplement No. 1 to the University Gazette, January 1964. Oxford: The University, 1964). The Subcommittee also believes that a fellowship tends to make its holder more effective academically and the inclusion of non-tutorial Fellows is a source of strength to a college as a place of learning and education. It did not think that all members of Congrogation, at any given time, could reasonably or properly be made Fellows of existing or future colleges, but agreed with the Harrison Report that there is at prosent a group of about 250 non-Fellows whose distinction or duties in teaching or research make them eligible for a place or status in the University equivalent to that of Fellows in existing Colleges. Some thirty of these, such as readers, are specially eligiblo for a fellowship, though not necessarily at an undergraduate college. Another sixty are fitted by undergraduate tutorial teaching and experience for a fellowship at an undergraduate college, and for most of these the Subcommittee believes that election to such a fellowship may be foasible. For the remainder, it believes that the right solution is to be found in new collegiate societies, and the Sub-committee suggests that at least two new societies are needed. One already exists in embryo as Linacre House, with 28 senior members of Senior Common Room and 150 junior members, and, it is suggested, that it should be established on an independent graduate college. The Sub-committee suggests that further consideration should bo given to the establishment of another society catering for senior members only or for both junior and senior members. It is assumed that the new socioties, of either type, would be non-residential, except for the head and one or two officers, but would have accommodation for meals, common-room facilities and possibly some teaching and seminar rooms. Detailed proposals would have to be worked out by a more representative committee and, at least at the outset, the University would have to contribute substantially to the cost. Tho Sub-committee's report was adopted by the Committee and, on February 25, approved by the Congregation.

The Imperial College of Science and Technology

THE annual report of the Imperial College of Science and Technology for 1962--63 includes the fifty-sixth annual report of the Governing Body and the Rector's report, to which are appended lists of publications during the year, of special addresses and lectures, statistics of staff and students, the statement of accounts and a list of university awards. Further progress is reported in the development of inter-disciplinary studies, and it is expected that the decision taken to link the College with the University's Atlas computer will meet the College's reasonable computing neods for the immediate future. The number of full-time students increased from 2,735 in 1961-62 to 2,879 , the increase being equally in undergraduate and postgraduate students. Of 732 degrees (including 199 higher degrees) awarded during the year, 46 per cent were science degrees. Of 316 awards of the D.I.C., 286 were to technologists. About 25 per cent of all students come from homes within 30 miles of the College and nearly half from other parts of the United Kingdom; 743 came from overseas, two-thirds from within the Commonwealth and of the overseas students three out of four were postgraduate. The academic staff increased by 40 to 493 , including two new professorships and three new readers. Research grants and contracts totalled $£ 440,000$ or about 13 per cent of the income of the College, 60 projects, totalling $f 187,600$ annually, being supported by the Department of Scientific and Industrial Research, and responsibility for 23 projects formerly sponsored by the Department wore transferred to the University Grants
Committec. Expenditure under research grants and contracts was $£ 534,992$.

\section{The Royal Society of Tasmania : Elections}

THE following have beon elected officers and member's of Council of the Royal Society of Tasmania for the year 1964: President, H.E. the Governor, Lieutenant-General Sir Charles Gairdner; Vice-Presidents, Prof. G. C. Wade and Mr. E. C. Gifford; Honorary Secretary and Honorary Librarian, Dr. W. Bryden; Honorary Treasurer, Mr. G. E. A. Hale; Council, Mr. R. A. Both, Mr. J. V. Cook, Mr. R. M. H. Garvie, Dr. D. Martin, Mr. E. R. Pretyman, Mr. T. E. Burns and Mr. W. F. Ellis.

\section{Announcements}

THE second meeting on "High Pressure Research" will be held at the National Physical Laboratory during June 2-3. Further information can be obtained from Dr. P. Lincoln Smith, National Physical Laboratory. Teddington, Middlesex.

AN open day will be held at the British Leather Manufacturers' Research Association, Egham, on May 12. Further information can be obtained from the secretary, British Leather Manufacturers' Research Association, Milton Park, Egham, Surrey.

AN international symposium on "Basic Science and Clinical Aspects of Muscle" will be held in the University of Alberta during June 1-4. Further information can be obtained from Dr. G. Monckton, University of Alberta Hospital, Edmonton, Alberta.

THE forty-seventh annual conference of the Chemical Institute of Canada will be held in Kingston. Ontario, during June 1-3. The conferenco will include a plenary session on "The Scientist and his Place in Society". Further information can be obtained from the Chemical Institute of Canada, 48 Rideau Street, Ottawa 2, Ontario.

A CONFERENCE on "Metallurgical Developments in High Alloy Steels", arranged jointly by the British Iron and Steel Research Association and the Iron and Steel Institute, will be held in Scarborough during June 2-4. Further information can be obtained from $\mathrm{Mr}$. J. R. Powell, British Iron and Steel Research Association, 24 Buckingham Gate, London, S.W.1.

A meeting on "Hydraulics", arranged by the Société Hydrotechnique de France, will be held during June 8-13. A conference on "Instabilities in Hydraulics and Fluid Mechanies" will be held in Lille during June 8-9, and the following days will be spent in a work tour of Holland. Further information can be obtained from La Société Hydrotechnique de France, 199 rue de Grenelle, Paris 7.

THE fourth intornational symposium on "The Action, Use and Natural Occurrence of Microbial Inhibitors in Foods", arranged by the Food Microbiology and Hygiene Section of the International Association of Microbiological Societios with the assistance of the Swedish Institute for Food Preservation Research, will be held in Gothenberg during June 2-5. Further information can be obtained from I). N. Molik, S.I.K., Källebäck, Gothenberg.

THe seventeenth annual summer conference of Brookhaven National Laboratory on "Subunit Structure of Proteins-Biochemical and Genetic Aspects" will bo held at the Laboratory during June 1-3. The programme will include sessions on: inter-allelic complementation; enzymatic aspects of subunit association; subunits in plant proteins; isozymes; physical chemistry of subunit interaction; mechanism and significance of subunit association; subunits in blood proteins; metabolic control. Further information can be obtained from the chairman of the symposium committee, Mr. S. Lacks, Brookhaven National Laboratory, Upton, Long Island N.Y. 11973. 